\title{
Epidemic of Chronic Kidney Disease of Nontraditional Etiology in El Salvador: Integrated Health Sector Action and South-South Cooperation
}

\author{
Raúl Herrera-Valdés MD MS PhD DSc, Miguel A. Almaguer-López MD MS, Carlos M. Orantes-Navarro MD, \\ Laura López-Marín MD MS, Elsy G. Brizuela-Díaz MD MPH, Héctor Bayarre-Vea MD PhD, Luis C. Silva-Ayçaguer PhD DSc, \\ Patricia Orellana de Figueroa, Magaly Smith-González, Yudit Chávez-Muñoz, Raymed Bacallao-Méndez MD MS
}

\begin{abstract}
In El Salvador, chronic kidney disease had reached epidemic proportions towards the end of this century's first decade. In 2011-2012, the Ministry of Health reported it was the leading cause of hospital deaths in men, the fifth in women, and the third overall in adult hospital fatalities. Farming was the most common occupation among men in dialysis (50.7\%). By 2017, chronic kidney disease admissions had overwhelmed hospital capacity.
\end{abstract}

In 2009, El Salvador's Ministry of Health, Cuba's Ministry of Public Health and $\mathrm{PAHO}$ launched a cooperative effort to comprehensively tackle the epidemic. The joint investigations revealed a total prevalence of chronic kidney disease in the adult population of farming communities higher than that reported internationally ( $18 \%$ vs. $11 \%-14.8 \%)$, higher in men than in women $(23.9 \%$ vs $13.9 \%)$ and higher in men who were farmers/ farmworkers than in men who were not (31.3\% vs. $14.8 \%)$. The disease was also detected in children. An association was found between chronic kidney disease and exposure to agrochemicals (OR 1.4-2.5). In 51.9\% of all chronic kidney disease cases, traditional causes (diabetes, hypertension, glomerulopathies, obstructive nephropathies and cystic diseases)

\section{INTRODUCTION}

Chronic kidney disease (CKD) mortality has increased worldwide, from an annual adjusted mortality rate of 9.6 per 100,000 population in 1990 to 11.1 per 100,000 in 2010[1] and 18.2 per 100,000 in 2016.[2]

Population-based epidemiologic studies in the USA have shown increased prevalence of CKD from 11\% (1988-1994) to $14.8 \%$ (2011-2014).[3,4] In 2011-2014, CKD prevalence was higher in US women than men (16.5\% vs. $13 \%)$ and in the population aged $>60$ years $(32.6 \%)$ than in the populations aged $40-59$ years (10.6\%) and 20-39 years (6.6\%).[4] In Cuba, the Isle of Youth Study (ISYS) reported a prevalence of $9.6 \%$ in population aged $\geq 20$ years (2004-2008)[5] and in El Salvador, the National Survey of Non-communicable Chronic Diseases in the Adult Population of El Salvador (ENECA-ELS) found 12.6\% (2014-2015).[6]

IMPORTANCE This article describes the results of a collaboration among El Salvador's Ministry of Health, Cuba's Ministry of Public Health and PAHO, and its contribution to the characterization of a new epidemic form of chronic kidney disease of nontraditional etiology with high mortality in Salvadoran farming communities. It also suggests an etiological hypothesis and actions to combat the disease, with implications for other affected countries and regions. were ruled out and the existence of a particular form of chronic kidney disease of nontraditional etiology was confirmed (whose initial cases were reported as early as 2002). In the patients studied, functional alterations and histopathologic diagnosis confirmed a chronic tubulointerstitial nephritis; most presented with neurosensory hearing loss, altered tendon reflexes and tibial artery damage.

The main results of this cooperation were the epidemiologic, physiopathologic, clinical and histopathologic characterization of chronic kidney disease of nontraditional etiology. This characterization facilitated case definition for the epidemic and led to the hypothesis of systemic toxicity from agrochemicals (e.g., paraquat, glyphosate), which particularly affect the kidneys and to which farmers/farmworkers (who may also become dehydrated in the fields) are most exposed. The research thus also laid the foundations for design of comprehensive intersectoral government actions to reduce cases and put an end to the epidemic.

KEYWORDS Chronic kidney disease; chronic renal failure; tubulointerstitial nephritis; epidemiology; histopathology; international cooperation; agrochemicals; environmental pollutants, noxae, and pesticides; occupational health; PAHO; El Salvador; Cuba
ISYS, a population-based epidemiologic study, was conducted in cooperation with the International Society of Nephrology and other international organizations, to assess the CKD situation in Cuba and associated risk factors.[5] The methodology and results of this study served as the foundation for subsequent studies in $\mathrm{El}$ Salvador, where in addition to CKD of traditional etiology, a new form of CKD of nontraditional etiology (CKDnT) has emerged, largely found in farming communities.[6]

The purpose of this article is to show how cooperation between Cuba and El Salvador (South-South cooperation) together with PAHO made it possible to conduct epidemiologic and clinical studies on the CKD and CKDnT epidemic in El Salvador's farming communities, and to develop health system capacity to address the epidemic.

\section{EL SALVADOR AND CKD}

The principal scientific evidence generated by the joint studies of CKD and CKDnT is summarized below. It includes confirmed prevalence; sociodemographic distribution; social determinants; risk factors; cause; extent of the epidemic; the clinical, physiopathologic and histopathologic patterns of disease; and an etiologic hypothesis for CKDnT. The integrated actions of the Salvadoran health system, South-South cooperation and prospects for future work are also described and analyzed.

Sociodemographic data In 2018, El Salvador had a population of $6,643,359,11.2 \%$ aged $\geq 60$ years, with a life expectancy of 
77.6 years for women and 68.6 for men.[7] The World Bank has classified El Salvador as a lower middle income country with a poverty index of $29.2 \%$.[8]

CKD and CKDnT situation The first scientific evidence of a new form of CKD in El Salvador was reported in 2002.[9] It was characterized by lack of association with diabetes mellitus, hypertension or other traditional causes, and by its presence in male farmers/farm workers living in rural communities (Hereafter, "farmer" refers to farm workers hired by landowners or companies, as well as to farmers who may work their own land, usually subsistence farmers in the Salvadoran communities studied).

After becoming Minister of Health in 2009, Dr María Isabel Rodríguez addressed CKD as a serious and complex health problem in the country. In 2011-2012, the Ministry of Health of El Salvador (MINSAL) confirmed that end-stage renal disease was the third leading cause of hospital death in adults, the leading cause in men and the fifth leading cause in women, with a casefatality rate of $12.6 \%$.[10] One of the main contributing factors was a new type of CKD, unexplained by traditional factors, that primarily affected farming communities.[10]

In order to tackle this health crisis, MINSAL devised and deployed new activities on different fronts. For example, it began new clinical, pathologic and epidemiologic research and strengthened health services (including surveillance systems in primary care) for CKD prevention and control. It also worked to raise international awareness about CKD and took action to address it.[10] MINSAL leadership successfully argued the need to designate CKD an emerging health problem in several international fora, among them PAHO's 2011 High-Level Regional Consultation of the Americas against NCDs and Obesity;[11] the 34th Regular Session of the Council of Ministers of Health of Central America and the Dominican Republic (COMISCA) in 2011 (resulting in the Antigua Declaration);[12] and the 37th Session of COMISCA in 2012, which adopted Resolution 54/55.[13]

These fora all recognized CKD as a health priority and underscored the need for immediate action. In 2013, as a result of the High-Level Meeting of Ministers of Health (which produced the San Salvador Declaration),[14] the disease was recognized as chronic tubulointerstitial kidney disease of Central America, based on the results of the epidemiologic, clinical and histopathologic studies conducted in El Salvador with CKD patients from farming communities. That same year, at the 52nd Directing Council of PAHO, agreement was reached to recognize CKDnT as a new entity, based on the San Salvador Declaration, and recommendations for action were formulated.[15]

In 2017, progress in implementing these recomendations were reviewed at the 160th Session of the PAHO Executive Committee. [16] The meeting also recognized El Salvador's progress in conducting and disseminating the results of ENECA-ELS 2015[6] and actions to comprehensively strengthen local capacity to respond to CKDnT in the affected areas. Also recognized were advances in epidemiologic surveillance systems, various intersectoral activities, development of protocols and a dialysis and kidney transplant registry, as well as human resource training.[15]

South-South cooperation In 2009, a technical cooperation agreement among MINSAL, Cuba's Ministry of Public Health
(MINSAP) and PAHO was implemented, providing the resources for epidemiological, clinical, and health services research for the comprehensive study and management of CKD and CKDnT in El Salvador.

For almost ten years, this cooperation has exemplified integration of professional and technical groups from different institutions and countries: in El Salvador, MINSAL, the National Institute of Health (INS), San Juan de Dios National Hospital of San Miguel, San Juan de Dios National Hospital of Santa Ana, primary care workers and facilities, students from the University of El Salvador Medical School, and Salvadoran farmers' organizations in the Bajo Lempa region; in Cuba, MINSAP, the National Nephrology Institute (INEF), the National School of Public Health (ENSAP) and Salvadoran students from Havana's Latin American Medical School (ELAM).

MINSAL oversaw the project led by Dr Rodríguez, during her tenure as Minister of Health and Director of INS, and later as Presidential Advisor for Health and Education. MINSAL furnished all logistical support for project implementation, from primary care to national hospitals. INS planned the project and provided equipment and reagents, coordinated by $\mathrm{Dr}$ Carlos Orantes Navarro. Community epidemiological studies were conducted in primary care, with social and farmers' organizations playing a key role in raising awareness and mobilizing community participation.

Work teams (which carried out research, health promotion and health care activities) were made up of primary care physicians, joined by students from ELAM and EI Salvador's Medical School during vacations, after receiving classroom and field training.

The national hospitals were the setting for clinical, physiopathologic and histopathologic studies, with multidisciplinary participation by 22 biomedical specialties. MINSAP provided a multidisciplinary team of specialists consisting of nephrologists, epidemiologists, nephropathologists, biochemists, toxicologists and biostatisticians from INEF and ENSAP. Cuban team members served as temporary $\mathrm{PAHO}$ advisors and were responsible for study methodology and implementation strategy under MINSAL guidance. In this context, the EI Salvador research process benefitted from Cuba's Isle of Youth Study,[5] which provided useful methodological experience for examining CKD in total populations, including its survey forms, physical and laboratory measurement techniques, human resource training and methods for data analysis.

During the research, CKD morbidity and mortality surveillance systems were upgraded, with emphasis on developing human and technical resources through in-service training for professionals and technicians and on building capacity for use of new equipment and diagnostic techniques in all hospitals and health centers conducting the studies. The training was expanded nationwide to primary care.

A new modern facility was also built in the eastern region of the country (Bajo Lempa), the area most affected by CKDnT: the Monsignor Romero Community Family Health Unit, containing a specialized kidney-care section. It was staffed with a nephrologist, nutritionist, psychologist, health educator, laboratory technician and health promotors, and was constructed with funds from the Spanish Agency for International Development Cooperation. 
The main results of the joint studies in El Salvador are discussed below.

\section{CKD AND CKDNT: JOINT RESEARCH RESULTS}

Epidemiological characterization Epidemiological research in farming communities Some epidemiological studies were carried out at different times.[6,17,19-23] In 2009-2013, 11 farming communities in 3 regions of the country were studied, with interviews of 1306 families and 5018 male and female adults aged $\geq 18$ years; almost $90 \%$ (4503) were reassessed for CKD with a second measurement of urine albumin and creatinine, 3 (or more) months later.[17] Overall CKD prevalence detected in this adult population was $18 \%,[17]$ higher than that reported internationally $(11 \%-14.8 \%)[18]$ or domestically $(12.8 \%)$.[17] The disease was more common in men, in farmers than in nonfarmers, and in male farmers than in female farmers (Table 1). $[17,19]$

Of total CKD cases in these communities, $51.9 \%$ (Table 1) were not diabetic or hypertensive and did not have proteinuria $\geq 1 \mathrm{~g} / \mathrm{L}$ (suggestive of glomerular disease), confirming the presence of a particular form of CKD not associated with these traditional risk factors or causes reported internationally. The resulting form was given a presumptive diagnosis of CKDnT.

In the population aged $<18$ years, CKD prevalence was $3.9 \%$ (Table 1). Glomerular hyperfiltration, calculated beginning at age 2 years, was observed in all ages and both sexes. An average glomerular filtration rate $\left(\mathrm{mL} / \mathrm{min} / 1.73 \mathrm{~m}^{2}\right)$ was obtained for ages 2-5 years (male, 174.4; female, 182.5), 6-12 (male, 166.4; female, 175.8) and 13-17 (male, 171.4; female, 160.5). The values obtained were higher than the normal reference values for these age groups and indicative of kidney damage at an early age. [20] These findings revealed that the disease appears in childhood and adolescence, with high prevalence in both sexes.

The environmental and occupational health research found long work hours in a setting marked by high temperatures, intense physical activity and poor hydration. It also revealed use of large quantities of agrochemicals without adequate protection or hygiene and presence of agrochemicals and heavy metals (cadmium and arsenic) in surface and groundwater, wells and sediments, to a greater extent on farmland than in residential areas.[21,22] Direct contact with agrochemicals $(46.7 \%)$ and use of nonsteroidal anti-inflammatories (NSAIDs) (84.2\%) were significant among nontraditional risk factors in this adult population.[17]

Poor housing conditions, deficient water quality, low educational levels, poor nutrition, inadequate health services and a polluted environment (factors associated with poverty) were identified as the most frequent social and environmental determinants. [20,22]

Taken together, these findings suggested that risk factors were associated with farming activity, although they jeopardized the communities at large. It was concluded that attention should focus on the social determinants and environmental factors characterizing the most affected communities.

National Survey of Chronic Non-communicable Diseases in Salvadoran Adult Population ENECA-ELS 2015 This was performed in 2014-2015.[6] It is the most complete and
Table 1: Prevalence of CKD and associated risk factors in EI Salvador in joint epidemiological studies

\begin{tabular}{l|r|r|r|}
\hline $\begin{array}{l}\text { CKD in farming communities, } \\
\text { population } \geq 18 \text { years, } \\
\text { 2009-2013[17,19] }\end{array}$ & $\begin{array}{r}\text { Male } \\
n=976\end{array}$ & $\begin{array}{c}\text { Female } \\
n=1412\end{array}$ & $\begin{array}{c}\text { Total } \\
n=2388\end{array}$ \\
\hline CKD (\%) & 23.9 & 13.9 & 18.0 \\
\hline CKD in farmers* (\%) & 31.3 & 15.8 & 26.8 \\
\hline CKD in nonfarmers (\%) & 14.8 & 13.4 & 13.8 \\
\hline CKDnT in cases with CKD (\%) & 45.3 & 6.6 & 51.9 \\
\hline
\end{tabular}

CKD in farming communities, population $<18$ years $(n=2115)[20]$

CKD $3.6 \quad 4.1 \quad 3.9$

National CKD prevalence by sex and location.

Population $\geq 20$ years (ENECA-ELS 2015)[6]

\begin{tabular}{|l|r|r|}
\hline Prevalence & $\%$ & Cl $95 \%$ \\
\hline CKD & 12.6 & $11.0-14.4$ \\
\hline Urban & 11.3 & $9.2-13.7$ \\
\hline Rural & 14.4 & $12.1-16.9$ \\
\hline Male & 17.8 & $14.6-20.5$ \\
\hline Female & 8.5 & $7.4-10.5$ \\
\hline${ }^{* *}$ CKDnT & 3.8 & $3.0-4.8$ \\
\hline Urban & 3.1 & $2.2-4.4$ \\
\hline Rural & 4.8 & $3.5-6.4$ \\
\hline Male & 6.0 & $4.6-7.9$ \\
\hline Female & 2.1 & $1.5-2.8$ \\
\hline
\end{tabular}

Agrochemicals as an associated risk factor $(\geq 5$ years of

exposure) ENECA-ELS case-control study[6]

\begin{tabular}{|l|r|r|}
\hline Exposure & OR & Cl 95\% \\
\hline Farming & 2.0 & $1.5-2.5$ \\
\hline $\begin{array}{l}\text { Handling of agrochemicals } \\
\text { Storage of spraying equipment and } \\
\text { products }\end{array}$ & 2.5 & $1.9-3.4$ \\
\hline $\begin{array}{l}\text { Handling of known nephrotoxic } \\
\text { agrochemicals }\end{array}$ & 1.4 & $1.2-2.0$ \\
\hline $\begin{array}{l}\text { Aerial spraying in work or } \\
\text { residential areas }\end{array}$ & 2.4 & $0.8-2.2$ \\
\hline $\begin{array}{l}\text { Direct exposure to agrochemicals } \\
\text { (occupation sprayer, mixer, }\end{array}$ & 1.8 & $1.7-3.4$ \\
\hline $\begin{array}{l}\text { formulator or flagman) } \\
\text { Consumption of river or well water }\end{array}$ & 1.8 & $1.4-2.4$ \\
\hline
\end{tabular}

*includes both paid farm laborers and farm owners

CKD: chronic kidney disease (GFR $<60 \mathrm{~mL} / \mathrm{min}$ or GFR $\geq 60 \mathrm{~mL} / \mathrm{min}$ with persistent albuminuria $>30 \mathrm{mg} / \mathrm{g})[6]$

${ }^{* *}$ CKDnT: chronic kidney disease of nontraditional etiology (diagnosis of CKD without history of hypertension, diabetes mellitus or albuminuria $>300 \mathrm{mg} / \mathrm{g})[6]$ GFR: glomerular filtration rate

OR: odds ratio

representative dataset available for CKD in El Salvador, characterized for its methodological rigor and use of internationally recommended methods for all measurements.[6,23] Implications of its epidemiological findings were important, as they revealed that the CKD and CKDnT problem was much more serious in rural areas and among men, and confirmed that CKDnT was not a national epidemic but selectively affected residents of farming communities. Concerning nontraditional risk factors, the relative frequency of the general population's direct exposure to agrochemicals was estimated at 12.6\%. As with the 2009-2013 epidemiological studies in farming communities, a nested casecontrol study conducted with ENECA-ELS survey data showed a strong association between CKD and exposure to agrochemicals for at least five years (OR 1.4-2.5) (Table 1).[6] 
Clinical, physiopathologic and histopathologic characterization of potential CKDnT cases A study to identify the clinical and histopathologic characteristics was conducted in 2013 by experts in 22 biomedical specialties.[24,25]

Clinical and physiopathologic characterization The main clinical and physiopathologic findings were: absence of dysmorphic hematuria; proteinuria $>1 \mathrm{~g}$; normal kidney ultrasound in all patients; relatively undamaged upper renal arteries, and in contrast, severe damage to tibial arteries, coinciding with the part of the body most exposed to agrochemicals used in spraying; marked electrolyte loss with electrolytic polyuria and positive markers for tubular damage; neurologic damage in the majority of patients, characterized by neurosensorial hearing loss and alteration of the osteotendinous reflexes from the earliest stages of the disease, not attributable to uremia; profuse sweating and inadequate hydration among male farmers due to long periods of intense work in high temperatures. The functional exploration studies were the most complete studies published internationally (Table 2).[24]

Renal histopathology[25] The basic findings were interstitial fibrosis and tubular atrophy, glomerular sclerosis, mild-to-moderate inflammatory interstitial mononuclear cell infiltrates and vascular damage with intimal proliferation, and thickening and vacuolization of the tunica media. The morphologic pattern described corresponds to chronic tubulointerstitial nephritis (Table 2).

Interstitial fibrosis, glomerular sclerosis and vascular damage were higher in men. Interstitial fibrosis and severe tubular atrophy were more marked in sugarcane workers, as was thickening of the arterial wall and vacuolization of the tunica media. These histopathologic findings were present in all cases, male and female, as an expression of common damage, observed from the early lesions of stage 2 of the disease to the advanced lesions of stage $3 \mathrm{~b}$. Kidney damage was greater in male farmers and those exposed to greater heat stress.[25]

Electron microscopy revealed myeloid structures and phagolysosomes in the cells of the proximal and distal tubules and in the cytoplasm of the arteriolar vascular smooth muscle cells, which could correspond to chemicals phagocytized by lysosomes.[25]

Inferences and hypothesis Clinical and physiopathologic findings above suggest (1) ruling out primary and secondary glomerular diseases, obstructive nephropathies and cystic diseases; (2) interpreting functional impairments as indicative of interstitial tubular damage and symptoms mentioned by patients as a consequence of electrolyte loss; and (3) a hypothesis of neurotoxicity with concomitant need to explore the possibility of chemically induced vascular damage.[26]

The functional and histopathologic findings support the hypothesis that CKDnT is a chronic tubulointerstitial nephritis, coupled with systemic manifestations of hearing loss, peripheral neuropathy and peripheral vascular damage, which are not traditionally associated with chronic kidney disease.[26]

Summarizing: the etiologic hypothesis is systemic toxicity affecting the kidney, likely from environmental and occupational exposure to toxic substances used in agriculture. Toxic exposure may be greater among farmers, and its effects are likely
Table 2: Characterization of CKDnT patients ( $n=46: 36$ men, 10 women )

CLINICAL/PHYSIOPATHOLOGIC[24]

CKD progression: stage 2 (32.6\%), stage 3a (23.9\%), stage 3b $(43.5 \%)$

\section{Risk factors}

Poverty (100\%); exposure to environmental toxins (95.7\%); farming occupation $(89.1 \%)$; male sex $(78.3 \%)$

General symptoms

Arthralgia (54.3\%), asthenia (52.2\%), loss of libido (47.8\%), cramps $(45.7 \%)$

Kidney symptoms

Nocturia $(65.2 \%)$, foamy urine $(63 \%)$, polyuria $(52.2 \%)$, dysuria

$(39.1 \%)$

\section{Clinical signs}

HT (21.7\%), diastolic dysfunction (43.5\%), LVH (15.2\%), tibial artery damage $(65.2 \%)$, altered osteotendinous reflexes $(43.5 \%)$, neurosensorial hearing loss $(56.5 \%)$, normal fundus of the eye $(100 \%)$, normal kidney ultrasound $(100 \%)$

\section{Kidney function}

Markers of kidney damage: no dysmorphic erythrocytes, A3 albuminuria $(82.6 \%)$, proteinuria $>1 \mathrm{~g}(2.2 \%)$, B2 microglobulin $(78.2 \%), \mathrm{N}-\mathrm{Ga}$ (26.1\%)

Urinary excretion of: magnesium (100\%), phosphorus (50\%), sodium $(45.7 \%)$, potassium $(23.9 \%)$, electrolyte polyuria $(43.5 \%)$

In blood: hyponatremia (47.8\%), hypocalcemia (39.1\%), hypopotassemia $(30.4 \%)$, metabolic alkalosis $(45.7 \%)$

\section{HISTOPATHOLOGIC[25]}

\section{Interstitial damage}

Interstitial fibrosis: men-mild to moderate (38.9\%), severe $(33.3 \%)$; women - mild to moderate (30\%)

Mild chronic inflammatory lymphomonocytic infiltration with $<25 \%$ of parenchyma affected

\section{Tubular damage}

Classic tubular atrophy: $89.1 \%$

Cytoplasmic vacuolization of proximal tubule epithelial cells: $45.6 \%$

\section{Glomerular damage}

Glomerulomegaly: $47.8 \%$

Glomerulosclerosis: men: $66.7 \%$; women: $30 \%$

\section{Vascular damage}

Fibrointimal proliferation: $19.6 \%$

Thickening of tunica media: $52.2 \%$

Vacuolization of tunica media: $43.5 \%$; C: $55.6 \%$; NC: $41.7 \%$

Immunofluorescence

Negative

\section{Electron microscopy}

Phagolysosomes

Myeloid structures

\section{Diagnosis}

\section{Chronic tubulointerstitial nephritis}

C: sugarcane workers CKD: chronic kidney disease CKDnT: chronic kidney disease of nontraditional etiology HT: hypertension

NC: non-sugarcane workers LVH: left ventricular hypertrophy $\mathrm{N}-\mathrm{Gal}$ : neutrophil gelatinase-associated lipocalin

synergistic with dehydration caused by heat stress during the workday. Within the multifactorial causality of such a complex disease, other risk factors were detected, among them NSAID consumption, a history of malaria, and others that may act as contributing factors.

Health services research in El Salvador Based on the findings of earlier studies, this research was conducted in 2018 to evaluate 
service capacity and quality, and links among MINSAL's levels and areas of care needed to comprehensively address the CKD epidemic.

Salvadoran authorities and Cuban researchers examined the country's health statistics, visited facilities at the different levels of care and reviewed their data.[27] Statistical analysis revealed that in overall mortality, CKD ranked fifth among the 10 leading causes of death, with 2710 deaths, for a rate of 41 per 100,000 population. However, when searching for CKD diagnosis under all designations and from multiple causes, CKD mentioned as 'any cause of death' increased by $141 \%$, raising the number of deaths to 3828 . Thus, CKD incidence, prevalence and mortality were very high. In 2017 , 6951 new cases (93.3 per 100,000 population) were reported, despite possible underreporting in all stages of the disease. CKD was the leading or second leading cause of mortality in the country's main hospitals, with the consequent hospital financial outlays.[28] Mortality in dialysis was also very high (33.8\%-42.8\%, with possible underreporting). Farming ranked first among dialysis patients' occupations (50.7\%).[29]

Despite the development of primary care in the wake of El Salvador's Health Reform,[30] the number of cases exceeded this level's capacity for preventive action, early diagnosis and effective medical attention. At the hospital level, most patients arrived in the terminal stage, and many died before undergoing dialysis; the numbers and seriousness of cases also overwhelmed hospital capacities. The number of nephrologists (eight per million population) and dialysis capacity were insufficient to provide care for the high number of patients.[27]

Rural communities were hardest hit, with double the burden of traditional and nontraditional risk factors. The bulk of patients were in their most productive years (30-59). Cooperative studies with Sri Lanka,[31] one of the Asian countries most affected by CKDnT, also found nontraditional factors, as in other countries where the epidemic is present in farming communities.[23]

In 2017, analysis of national health and hospital statistics revealed other important health problems that may have a bearing on CKD and CKDnT. For example, extreme obstetric morbidity was found to be very high $(8 \%)$, its increasing trend mainly due to hypertensive disorders (preeclampsia). In 2017, the San Juan de Dios National Hospital (San Miguel), which serves the eastern region (where CKD and CKDnT are most prevalent), extreme obstetric morbidity occurred in $33.8 \%$ of births from urban areas and $64.1 \%$ of births from rural areas. Other notable indicators were the high rates of low birthweight $(8 \%)$, prematurity $(8 \%)$, birth defects $(12.6 \%)$ and infant mortality (9.2\%).[32] The literature reports an association between agrochemical exposure and placental toxicity, presence of agrochemicals in the umbilical cord and preeclampsia,[33] making these findings a topic for special attention in future studies involving CKD and CKDnT.

The high prevalence of obstetric complications[32] and high frequency of kidney dysfunction in children[20] suggest that the disease begins in the preconception period and progresses throughout life. More research is needed on the causes of the high CKD prevalence in children and adolescents and its possible link to the epidemic of chronic tubulointerstitial nephritis in farming communities in El Salvador, exposure to agrochemicals, NSAIDs, hard and stressful labor and chronic dehydration.

\section{FUTURE DIRECTIONS: A CALL TO ACTION}

The studies conducted have contributed to greater understanding of the epidemic afflicting rural El Salvador as described in this paper, and more are needed to identify and confirm causes and synergistic behaviors of risk factors. However, this alarming health situation requires swift action that cannot wait for the results of research that has not even begun.

The following actions, disaggregated by component, are considered necessary to address the health situation in El Salvador created by CKD and its variant, CKDnT.

Health promotion Strengthen social communication strategies and educational programs, as well as the legal and regulatory framework for environmental cleanup and preservation, to prevent and control CKD and CKDnT, protecting the health of farmers, their communities and the general population.

Prevention at the three levels of the health care system This implies upgrading and improving service quality:

- Swiftly adopt precautionary and preventive measures applied to agricultural and environmental practices, together with continued etiologic research.

- Strengthen health system capacity to implement a comprehensive approach to CKD and CKDnT, chiefly in the affected areas.

- Improve implementation, capacity building and compliance monitoring of existing programs or plans, as well as therapeutic guidelines for prevention, diagnosis, treatment and followup of CKD and CKDnT patients.

- Improve performance in primary care and provide laboratories with the diagnostic tools needed to actively screen at-risk groups and ensure early diagnosis of CKD and CKDnT; if possible, study the entire population in areas with high CKDnT prevalence.

- Strengthen capacity to provide inpatient and outpatient renal replacement therapy under the principle of bringing dialysis services closer to where patients live.

- Improve dialysis quality, develop kidney transplant capabilities, improve human resource capacity building and train more nephrologists.

\section{Surveillance systems and health statistics}

- Strengthen epidemiological, occupational and environmental surveillance systems.

- Improve CKD and CKDnT morbidity and mortality registries.

- Improve primary data quality.

- Implement the Kidney Dialysis and Transplantation Registry.

\section{Research}

- Increase advocacy for international cooperation among institutions and countries in research, and development of human and health care resources.

- Prioritize toxicology research on agrochemicals, both biotic and abiotic, including experimental studies.

- Improve quality of care and health service organization to create a favorable environment for research in all health facilities.

- Delve deeper into the causes of the increase in extreme obstetric morbidity. 


\section{CONCLUSIONS}

Collaboration among $\mathrm{PAHO}$ and the health ministries of $\mathrm{EI}$ Salvador and Cuba, facilitating joint work of Salvadoran and Cuban experts, contributed to better knowledge about the CKDnT epidemic in El Salvador, leading to the conclusion that it is widespread, selectively affects farming communities, results in high mortality (especially among people of productive age), and overwhelms the health system's capacity to provide care. Moreover, it is concentrated in farming communities with three basic factors that, taken together, set them apart: poverty as the predominant social determinant; an environment contaminated with agrochemicals; and working conditions marked by heat stress and dehydration, with no protection for workers. These factors coincide with those of other countries where the epidemic is found in farming communities.

The fact that CKDnT also affects residents of these communities who are not themselves farmers-for example, women who work at home, children and adolescents (not subject to the extreme heat stress of the work environment)supports the hypothesis of toxic environmental exposure as a main causal agent, perhaps aggravated or associated with other factors. The presence of kidney dysfunction in children and adolescents and the high prevalence of obstetric complications in women suggest that generations already may be doomed to suffer the effects of the disease, with catastrophic social and economic consequences for the country in the short and medium term.

The results of collaboration have laid the groundwork for the integrated intersectoral action urgently needed to combat the epidemic. Political and government commitment to take such action (involving not only health, but also sectors such as environment, social welfare, agriculture and business, as well as civil society represented by trade unions, community associations, farmers' groups, churches and others) is a prerequisite for any successful effort to improve health-including, of course, tackling the CKDnT epidemic. MINSAL, as the lead agency responsible for the health of the Salvadoran population, has the key role to play in coordinating these activities. The international community should also pay particular attention to this health crisis and must be ready to contribute to make national initiatives feasible.

\section{ACKNOWLEDGMENTS}

The authors are grateful to MINSAL, MINSAP, PAHO, and Dr María Isabel Rodríguez, as well as the community organizations and hundreds of health workers who made this cooperation possible. -1 h

\section{REFERENCES}

1. Lozano R, Naghavi M, Foreman K, Lim S, Shibuya K, Aboyans V, et al. Global and regional mortality from 235 causes of death for 20 age groups in 1990 and 2010: a systematic analysis for the Global Burden of Disease Study 2010. Lancet. 2012 Dec 15;380(9859):2095-128.

2. GBD 2016 Causes of Death Collaborators. Global, regional and national age-sex specific mortality for 264 causes of death, 19802016, a systematic analysis for the Global Burden of Disease Study 2016. Lancet. 2017 Sep 16;390(10100):1151-210.

3. Coresh J, Astor BC, Greene T, Eknoyan G, Levey AS. Prevalence of chronic kidney disease and decreased kidney function in the adult US population: third national health and nutrition examination survey. Am J Kidney Dis. 2003 Jan;41(1):1-12.

4. United States Renal Data System. 2017 USRDS Annual Report. Chapter 1. CKD in the general population [Internet]. Washington, D.C.: United States Renal Data System; 2017 [cited 2018 Aug 30]. p. 1-30. Available from: https://www.usrds .org/2017/download/v1_c01_GenPop_17.pdf

5. Herrera Valdés $R$, Almaguer López $M$, Chipi Cabrera JA, Pérez Díaz-Oliva J, Silva Ayçaguer LC. Prevalence of chronic kidney disease and associated risk factors in Cuba. In: Garcia G, editor. Chronic Kidney Disease in disadvantaged population. 1st ed. San Diego: Academic Press; 2017. Section 6.

6. Ministry of Health (SV). Encuesta nacional de enfermedades crónicas no transmisibles en población adulta de El Salvador ENECAELS 2015. Resultados relevantes [Internet]. EI Salvador: Ministry of Health (SV); 2015 [cited 2018 Aug 30]. 36 p. Available from: http://www .salud.gob.sv/archivos/comunicaciones/archi vos_comunicados $2017 /$ pdf/presentaciones _evento20032017/01-ENECA-ELS-2015.pdf. Spanish.

7. Dirección General de Estadísticas y Censos (DIGESTYC). El Salvador. Estimaciones y proyecciones de población nacional 2005-2025 [Internet]. El Salvador: Dirección General de Estadísticas y Censos (DYGESTYC); 2005 [cited 2018 Aug 30]. Available from: http://www.digestyc.gob.sv/ index.php/novedades/avisos/540-el-salvador -estimaciones-y-proyecciones-de-poblacion .html. Spanish.

8. World Bank [Internet]. New York: World Bank; c2019. Datos. El Salvador; 2017 [cited 2018 Aug 30]. Available from: https://datos.bancomundial .org/pais/el-salvador. Spanish.

9. García-Trabanino R, Aguilar R, Silva CR, Mercado MO, Merino RL. Nefropatía terminal en pacientes de un hospital de referencia en El Salvador. Rev Panam Salud Pública. 2002 Sep;12(3):202-6. Spanish.

10. Rodríguez MI. Chronic kidney disease in our farming communities: implications of an epidemic. MEDICC Rev. 2014 Apr;16(2):77-8.

11. Pan American Health Organization. Consulta Regional de Alto Nivel de las Américas sobre Enfermedades No Transmisibles y Obesidad [Internet]. Mexico, D.F.: Pan American Health Organization; 2011 Feb 25 [cited 2019 Jul 10]. 43 p. Available from: https://www.paho.org/hq/ dmdocuments/2011/Reporte-Mexico-Esp.pdf. Spanish.

12. XXXIV Reunión del Consejo de Ministros de Salud de Centroamérica y República Dominicana (COMISCA). Resolución [Internet]. Ciudad de Antigua (GT): Sistema de la Integración Centroamericana; 2011 Jun 27 [cited 2019 Jul 10]. 13 p. Available from: https://www.sica.int/Consulta/ Documento.aspx?Idn=60666\&idm=1. Spanish.

13. XXXVII Reunión del Consejo de Ministros de Salud de Centroamérica y República Dominicana (COMISCA). Resolución [Internet]. Managua: Sistema de la Integración Centroamericana; 2012 Dec 4 [cited 2019 Jul 10]. 14 p. Available from: https://www.paho.org/nic/index.php?option=com docman\&view=download\&alias $=438$-reso Iuciones-xxxvii-reunion-ordinaria-del-comis ca-dic-2012\&category_slug=documentos -estrategicos\&ltemid=235. Spanish

14. Ministry of Health (SV). Reunión de Alto Nivel de los Ministros de Salud. Declaración de San Salvador. Abordaje integral de la enfermedad renal túbulointersticial crónica de Centroamérica (ERTCC) que afecta predominantemente a las comunidades agrícolas [Internet]. San Salvador: Ministry of Health (SV); 2013 Apr 26 [cited 2019 Jul 10]. 6 p. Available from: http://www.salud .gob.sv/archivos/comunicaciones/archivos co municados2013/pdf/Declaracion_San\%20Salva dor_ERCnT_26042013.pdf. Spanish.

15. Pan American Health Organization. CD52/8: Chronic Kidney Disease in Agricultural Communities in Central America [Internet]. Washington D.C.: Pan American Health Organization; 2013 [cited 2019 Jul 10]. Available from: http://iris .paho.org/xmlui/handle/123456789/4401

16. Pan American Health Organization. La enfermedad renal crónica en comunidades agrícolas de Centroamérica: informe de progreso. 160 sesión del Comité Ejecutivo. CE160/INF/8 [Internet]. Washington, D.C.: Pan American Health Organization; 2017 May 2 [cited 2018 Aug 30]. 6 p. Available from: https://www .paho.org/hq/index.php?option=com_doc man\&view=download\&category_slug $=160$-es-92 75\&alias $=40410$-ce 160 -inf-8-b-s-410\&Itemid =270\&lang=en. Spanish.

17. Orantes CM, Herrera R, Almaguer M, Brizuela EG, Nuñez L, Alvarado N, et al. Epidemiology of chronic kidney disease in adults of Salvadoran agricultural communities. MEDICC Rev. 2014 Apr;15(2):23-30.

18. Xie $\mathrm{Y}$, Bowe B, Mokdad AH, Xian H, Yan $\mathrm{Y}$, Li $\mathrm{T}$, et al. Analysis of the Global Burden of Disease study highlights the global, regional, and national trends of chronic kidney disease epidemiology from 1990 to 2016. Kidney Int. 2018 Sep;94(3):567-81.

19. Orantes Navarro CM, Herrera Valdés R, López MA, Calero DJ, Fuentes de Morales J, Alvarado Ascencio NP, et al. Epidemiological characteristics of chronic kidney disease of non-traditional causes in women of agricultural communities of El Salvador. Clin Nephrol. 2015;83(7 Suppl. 1):S24-31.

20. Orantes-Navarro CM, Herrera-Valdés R, Almaguer-López M, Brizuela-Díaz EG, Alvarado- 
Ascencio NP, Fuentes-de Morales EJ, et al. Chronic kidney disease in children and adolescents in Salvadoran farming communities: $\mathrm{Ne}-$ frosalva Pediatric Study (2009-2011). MEDICC Rev. 2016 Jan-Apr;18(1-2):23-30.

21. Mejía R, Quinteros E, López A, Ribó A, Cedillos $\mathrm{H}$, Orantes Navarro CM, et al. Pesticide-handling practices in agriculture in El Salvador: an example from 42 patient farmers with chronic disease in the Bajo Lempa Region. Occup Dis \& Environ Med. 2014 Aug;2(2):56-70.

22. Quinteros E, Ribó A, Mejía R, López A, Belteton W, Comandari A, et al. Heavy metals and pesticide exposure from agricultural activities and former agrochemical factory in a Salvadoran rural community. Environ Sci Pollut Res Int. 2017 Jan;24(2):1662-76.

23. Orantes-Navarro CM, Almaguer-López MM, Alonso-Galbán P, Díaz-Amaya M, Hernández S, Herrera-Valdés $\mathrm{R}$, et al. The chronic kidney disease epidemic in El Salvador: a cross-sectional study. MEDICC Rev. 2019 Apr-Jul;21(2-3):29-37.

24. Herrera R, Orantes CM, Almaguer M, Alonso P, Bayarre HD, Leiva IM, et al. Clinical characteristics of chronic kidney disease of nontraditional causes in Salvadoran farming communities. MEDICC Rev. 2014 Apr;16(2):39-48.

25. López-Marín L, Chávez Y, García XA, Flores WM, Garcia YM, Herrera R, et al. Histopathology of chronic kidney disease of unknown etiology in Salvadoran agricultural communities. MEDICC Rev. 2014 Apr;16(2):49-54.

26. Orantes-Navarro CM, Herrera-Valdés R, Almaguer-López M, López-Marín L, Vela-Parada XF, Hernández-Cuchillas $M$, et al. Toward a comprehensive hypothesis of chronic interstitial nephritis in agricultural communities. Adv Chronic Kidney Dis. 2017 Mar;24(2):101-6.

27. Pan American Health Organization. Informe de Cooperación Técnica entre El Salvador, Cuba a través de la Organización Panamericana de la Salud (OPS). Desarrollo de estrategias operativas para el abordaje integral de la enfermedad renal crónica y sus factores de riesgo tradicionales y no tradicionales en El Salvador. San Salvador: Pan American Health Organization; 2018 Sep 11. Spanish.

28. Ministry of Health (SV) [Internet]. San Salvador: Ministry of Health (SV); c2017. La salud es un derecho, estamos para garantizarlo. Informe de Labores 2016-2017 [Internet]. San Salvador: Ministry of Health (SV); 2018 [cited 2019 Jul 10]. Available from: http://www.salud.gob.sv/download/ informe-de-labores-2016-2017/. Spanish.

29. Ministry of Health (SV) [Internet]. Salvador: Ministry of Health (SV); 2018 [cited 2019 Jul
10]. Sistema de Información de Enfermedades Crónicas. (SIEC). Registro Nacional de Diálisis y Trasplante. Available from: https://siec.salud .gob.sv/admin/login?_moduleSelection=ERC Spanish.

30. Ministry of Health (SV) [Internet]. San Salvador: Ministry of Health (SV); c2019. Transformación de la salud en El Salvador. Diez años de reforma hacia la salud universal [Internet]. San Salvador: Ministry of Health (SV); 2019 May [cited 2019 May 20]. 127 p. Available from: https://www .salud.gob.sv/22-05-2019-ministra-presenta -libro-transformacion-de-la-salud-en-el-salvador -10-anos-de-reforma-hacia-la-salud-universal/\#. Spanish.

31. Jayasumana $C$, Orantes $C$, Herrera R, Almaguer M, López L, Silva LC, et al. Chronic interstitial nephritis in agricultural communities: a worldwide epidemic with social, occupational and environmental determinants. Nephrol Dial Transplant. 2017 Feb 1;32(2):234-41

32. Ministry of Health (SV). Salud Universal, compromiso de país. Informe de Labores 2017-2018 [Internet]. San Salvador: Ministry of Health (SV) 2019 May [cited 2019 Jul 10]. Available from: http://www.salud.gob.sv/download/informe-de -labores-2017-2018/. Spanish.

33. Zhang $X$, Wu $X$, Lei $B$, Jing $Y$, Jiang $Z$, Xinyu $Z$. Transplacental transfer characteristics of organochlorine pesticides impaired maternal and cord sera, and placentas and possible influencing factors. Environ Pollut. 2018 Feb;233:446-54

\section{THE AUTHORS}

Raúl Herrera-Valdés (Corresponding author: raul.herrera@infomed.sld.cu),nephrologist with a master's degree in epidemiology, doctorate in medical sciences and advanced doctorate in science. Full and consulting professor and distinguished researcher, National Nephrology Institute (INEF), Havana, Cuba; PAHO temporary advisor.

Miguel A. Almaguer-López, nephrologist with a master's degree in epidemiology. Associate and consulting professor and distinguished researcher, INEF, Havana, Cuba; PAHO temporary advisor.

Carlos M. Orantes-Navarro, nephrologist. National Renal Research Coordinator, Nationa
Health Institute, Ministry of Health (MINSAL), San Salvador, El Salvador.

Laura López-Marín, physician specializing in anatomical pathology with a master's degree in atherosclerosis. Associate professor, INEF, Havana, Cuba.

Elsy G. Brizuela-Díaz, general practitioner with a master's degree in public health, Metropolitan Regional Public Health Department, San Salvador, El Salvador.

Héctor Bayarre-Vea, physician specializing in biostatistics with a doctorate in health sciences. Full professor, National School of Public Health (ENSAP), Havana, Cuba.

Luis C. Silva-Aycaguer, mathematician with a doctorate in mathematics and advanced doctorate in science. Consulting professor and distinguished researcher, ENSAP, Havana, Cuba.

Patricia Orellana de Figueroa, laboratory technician. Coordinator, National Laboratory Network, MINSAL, San Salvador, EI Salvador.

Magaly Smith-González, biochemist, Department of Renal Physiopathology, INEF, Havana Cuba.

Yudit Chávez-Muñoz, cytopathology technician, Department of Anatomical Pathology, INEF, Havana, Cuba.

Raymed Bacallao-Méndez, nephrologist with master's degrees in urgent care medicine and diagnostic procedures. Associate professor and senior researcher, INEF, Havana, Cuba.

Submitted: March 11, 2019

Approved for publication: August 8, 2019

Disclosures: None 